\title{
PERSEPSI NASABAH TERHADAP PENERAPAN 7P DALAM PEMASARAN PRODUK KUR PT BANK RAKYAT INDONESIA (PERSERO) TBK.UNIT TOMOHON UTARA KOTA TOMOHON
}

\author{
Prisca Seyla Glady Tumewu \\ Joachim N.K. Dumais \\ Lorraine W. Th. Sondak
}

\begin{abstract}
ABSRACT
The objective of this research is to analyze the perception of consumers towards the implementation of the marketing $7 P$ people KUR PT Bank Rakyat Indonesia (Persero) Tbk. Northen Tomohon Unit, Tomohon City by using the concept of a Likert Scale to analyze $7 P$ (product, price, place, promotion, people, physical evidence and process). The research was conducted in October through December 2016, using primary and secondary data. Sampling technique using purposive sampling method and sample size is 88 respondents. The analitycal method used is descriptive data analysis to describe the perception customer towards the implementation of the program $7 P$ KUR Bank Rakyat Indonesia Unit in northern city of Tomohon. To measure the perception was used Likert Scale. The results showed that the perception of customer satisfaction index score towards the delivery service kredit of the people in the bank BRI Nothen Tomohon Unit, Tomohon city is at its $84,41 \%$ and relatively strongly agree (SS).
\end{abstract}

Keywords: Customer Perception, Implementation Of, Product Marketing, Kur Bank Rakyat Indonesia, Tomohon City

\begin{abstract}
ABSTRAK
Penelitian ini bertujuan untuk untuk menganalisis persepsi nasabah terhadap penerapan 7P dalam pemasaran KUR PT Bank Rakyat Indonesia (Persero) Tbk. Unit Tomohon Utara Kota Tomohon, yaitu dengan menggunakan konsep Skala Likert untuk menganalisis 7P (product, price, place, promotion, people, physical evidence dan process). Penelitian ini dilaksanakan pada bulan Oktober sampai Desember 2016, menggunakan data primer dan sekunder. dengan teknik pengambilan sampel metode purposive sampling dan responden sebanyak 88 orang. Metode analisis yang digunakan adalah analisis data deskriptif yang menggambarkan Persepsi Nasabah Terhadap Penerapan 7P Dalam Program KUR Bank BRI Unit Tomohon Utara Kota Tomohon. Untuk mengukur persepsi dari nasabah Penerapan 7P Dalam Program KUR Bank BRI Unit Tomohon Utara Kota Tomohon, di gunakan Skala Likert. Hasil penelitian menunjukkan bahwa angka indeks persepsi kepuasan nasabah terhadap pelayanan penyaluran kredit usaha rakyat pada Bank BRI Unit Tomohon Utara Kota Tomohon adalah sebesar $84.41 \%$ dan tergolong Sangat Setuju (SS).
\end{abstract}

Kata kunci: Persepsi Nasabah, Penerapan 7P, Pemasaran Produk, Kur Bank Rakyat Indonesia, Tomohon Utara 


\section{PENDAHULUAN}

\section{Latar Belakang}

Perbankan merupakan bagian yang sangat penting dalam perekonomian, salah satunya sebagai lembaga intermediasi yang tugasnya menghimpun dana dari masyarakat dan menyalurkannya kembali dalam bentuk kredit. Menurut data bank Indonesia, bahwa dunia perbankan Indonesia sejak tahun 2008 menyalurkan Kredit Modal Kerja lebih banyak dibandingkan kredit yang lain (Kredit Konsumsi dan Investasi) (Fitriani, 2012). Sektor perbankan bertujuan menunjang pelaksanaan pembangunan nasional dalam rangka meningkatkan pemerataan, pertumbuhan ekonomi dan stabilitas nasional kearah peningkatan rakyat banyak juga memiliki fungsi utama adalah sebagai penghimpun dana dan penyalur dana masyarakat (UU no.10 Tahun 1998). Sektor perbankan menyalurkan program kredit pertanian yaitu kredit yang diberikan kepada perkebunan, peternakan dan perikanan. Dapat dikatakan bahwa keberadaan program perkreditan pertanian oleh perbankan merupakan salah satu unsur pelancar bagi keberhasilan dalam program pembangunan sektor pertanian.

Bank Rakyat Indonesia (BRI) merupakan salah satu lembaga keuangan perbankan yang menyediakan pembiayaan kepada petani, seperti KUR dan KUR-Mikro KKP-E yaitu produk kredit bank dengan skala mikro yang khusus untuk pembiayaan sektor pertanian. Pemberian kredit oleh BRI pada hakikatnya ditujukan kepada masyarakat atau nasabah. Bank Rakyat Indonesia (BRI) merupakan salah satu bank yang telah ditunjuk oleh pemerintah dan dipercaya untuk melaksanakan kebijakan mengenai KUR (Kotler \& Armstrong, 2001).

Dunia usaha bidang jasa, salah satunya yaitu bidang perbankan, pemasaran sangat dibutuhkan untuk memutarkan kas atau modal yang ada demi kelangsungan hidup bank tersebut, tentunya untuk memenuhi kebutuhan nasabah dan memberikan kepuasan terhadap nasabah. Oleh karena itu, Bank Rakyat Indonesia (BRI) perlu mencari strategi pemasaran yang efektif dan berkesinambungan untuk jangka panjang. Strategi yang digunakan oleh perbankan untuk mempengaruhi keputusan nasabah dalam memilih KUR salah satunya adalah dengan menerapkan strategi bauran pemasaran (marketing mix). Menurut Kotler (2008) bauran pemasaran adalah merupakan kombinasi dari empat variabel penting dari konsep pemasaran yang dapat dikendalikan oleh pihak bank untuk mempengaruhi reaksi para nasabah. Pihak bank dapat menarik nasabah melalui kegiatan pemasaran yang mencakup halhal sebagai berikut: Product, Price, Promotion dan Place atau dikenal dengan marketing mix (bauran pemasaran), pendekatan ini berhasil dengan baik. Namun menurut Lupiyoadi (2008), elemen-elemen tambahan sangat diperlukan dalam bisnis jasa, yaitu: People, Physical evidence dan Process dimana elemen tambahan tersebut dapat menghasilkan perbedaan yang sangat besar dalam kepuasan nasabah. Ketujuh variabel dalam bauran pemasaran ini, merupakan himpunan variabel yang dapat dikendalikan dan digunakan oleh perusahaan untuk mempengaruhi tanggapan nasabah dalam pasar sasarannya. Variabel atau kegiatan tersebut perlu dikombinasikan dan dikoordinasikan oleh perusahaan seefektif mungkin dalam melakukan tugas atau kegiatan pemasarannya.

Persepsi atau cara pandang nasabah terhadap KUR yang diberikan oleh pihak bank merupakan penilaian dari nasabah terhadap pelayanan dari pihak bank. Persepsi nasabah terhadap pelayanan penyaluran KUR dapat mempengaruhi keputusan nasabah untuk memanfaatkan dengan baik paket KUR yang ada dan secara berkelanjutan. Pihak bank juga harus memahami apa yang nasabah pikirkan dan rasakan tentang pelayanan penyaluran KUR apakah memberikan kepuasan kepada nasabah atau tidak, kepuasan muncul dari dalam hati dengan perasaan senang setelah membandingkan persepsi atau kesannya terhadap kinerja atau hasil suatu produk dan harapan - harapannya, kepuasan tinggi menciptakan kelekatan emosional terhadap produk atau jasa tertentu dan hasilnya adalah loyalitas nasabah terhadap bank BRI, sehubungan dengan Visi dari Bank BRI yaitu menjadi bank komersial terkemuka yang selalu mengutamakan kepuasan nasabah, dan salah satu misi yaitu memberikan pelayanan prima kepada nasabah melalui jaringan kerja yang tersebar luas dan didukung oleh sumber daya manusia yang profesional. Hal inilah yang menyebabkan penulis tertarik melaksanakan penelitian tentang Persepsi Nasabah Terhadap Penerapan 7P Dalam Strategi Pemasaran Produk KUR Bank Rakyat Indonesia (BRI) Unit Tomohon Utara Kota Tomohon. 


\section{Perumusan Masalah}

Pembiayaan KUR Bank Rakyat Indonesia (BRI) adalah satu program pemerintah yang baik kepada masyarakat menengah kebawah terutama dalam meningkatkan usaha masyarakat. Persepsi Nasabah Terhadap Penerapan 7P dalam pemasaran KUR Bank Rakyat Indonesia (BRI) dapat mempengaruhi peningkatan penyaluran KUR. Berdasarkan latar belakang pemikiran di atas, maka dapatlah dirumuskan masalah yang akan dikaji dalam penelitian ini, yaitu : Bagaimana persepsi nasabah terhadap Pelayanan penyaluran KUR ditinjau dari penerapan 7P oleh Bank Rakyat Indonesia (BRI) Unit Tomohon Utara kota Tomohon.

\section{Tujuan dan Manfaat Penelitian}

Penelitian ini bertujuan:

Untuk menganalisis persepsi nasabah terhadap penerapan 7P dalam pemasaran KUR Bank Rakyat Indonesia (BRI) Unit Tomohon Utara Kota Tomohon.

Manfaat penelitian:

1. Bagi peneliti dapat melatih cara berpikir serta menganalisis data dan penelitian ini merupakan salah satu syarat untuk memperoleh gelar sarjana di fakultas pertanian universitas sam ratulangi manado.

2. Bagi pihak Bank BRI, diharapkan dapat menjadi bahan pertimbangan dalam menentukan prinsip 7P (marketing mix) dalam peningkatan pelayanan KUR Bank Rakyat Indonesia (BRI) Unit Tomohon Utara Kota Tomohon. Bagi peneliti lain, dapat dijadikan referensi kajian dalam bidang penelitian serupa.

\section{METODOLOGI PENELITIAN}

\section{Waktu Dan Tempat Penelitian}

Penelitian ini dilaksanakan selama 3 (tiga) bulan dari bulan Oktober hingga bulan Desember 2016. Tempat penelitian dilaksanakan di Bank Rakyat Indonesia (BRI) Unit Tomohon Utara Kota Tomohon.

\section{Jenis - jenis Data}

Data yang digunakan dalam penelitian ini adalah menggunakan data primer dan data sekunder.

a. Data Primer

Data yang diperoleh dari Bank Rakyat Indonesia (BRI) Unit Tomohon Utara Kota Tomohon dan informasi yang didapat dari nasabah KUR itu sendiri. meliputi product yang ditawarkan dan kualitas KUR, price/jumlah uang yang harus dibayar atau dikeluarkan dalam pemasaran produk KUR, place yang menyangkut tempat, promotion bagaimana cara perusahaan mempromosikan produk KUR, people menyangkut orang-orang yang terkait didalam proses pemasaran KUR, physical evidence menyangkut bukti fisik yang dapat menunjang proses KUR ini dan process proses ketika pihak perusahaan berinteraksi dengan pihak lain dalam dipasarkannya produk KUR ini.

b. Data Sekunder

Data yang diperoleh dari buku-buku, jurnal penelitian dan literatur-literatur yang berkaitan dengan pembahasan permasalahan yang memiliki hubungan dengan penelitian ini

\section{Metode Pengumpulan Data}

Untuk melengkapi hasil penelitian ini, maka penulis melakukan pengumpulan data dengan menggunakan:

1. Kuesioner: Teknik pengumpulan data dengan cara memberikan daftar pertanyaan yang disebarkan pada nasabah KUR Bank Rakyat Indonesia (BRI) Unit Tomohon Utara Kota Tomohon sebagai responden untuk diisi (menggunakan skala likert).

2. Wawancara : Dilakukan wawancaara kepada pimpinan dan Karyawan KUR (Mantri KUR) Bank Rakyat Indonesia (BRI) Unit Tomohon Utara Kota Tomohon mengenai KUR itu sendiri.

\section{Populasi dan Sampel}

Populasi adalah keseluruhan objek penelitian dimana populasi termasuk dalam populasi tak terhingga. Namun, populasi dapat diwakili oleh sebagian anggotanya yang disebut dengan sampel. Sampel adalah bagian dari jumlah data dan karakteristik yang dimiliki oleh populasi tersebut (Sugiyono, 2007 dalam Thesman dan Utama, 2010). Target populasi dalam penelitian ini adalah Nasabah KUR Populasi nasabah dalam penelitian ini adalah seluruh (nasabah) yang menjadi anggota KUR Bank Rakyat Indonesia (BRI) Unit Tomohon Utara Kota Tomohon pada tahun 2016 yang tercatat aktif berjumlah 719 nasabah. Ukuran sampel nasabah KUR Bank BRI Unit Tomohon Utara ditentukan dengan menggunakan rumus Slovin (Consuelo dkk., 1993 dalam Yuliarmi dan Putu, 2007) :

$$
\begin{aligned}
& \mathrm{n}=\frac{\mathrm{N}}{1+\mathrm{Ne}^{2}}=\frac{719}{1+\left(719 \times 0,1^{2}\right)} \\
& =87,78 \text { atau dibulatkan 88 sampel }
\end{aligned}
$$


$\mathrm{n}=$ Ukuran sampel

$\mathrm{N}=$ Ukuran populasi

$\mathrm{e}=$ Tingkat kesalahan yang ditoleransi, yaitu

(10\%). Teknik pengambilan sampel nasabah KUR

Bank Rakyat Indonesia (BRI) Unit Tomohon

Utara Kota Tomhon adalah purposive sampling.

Purposive sampling, yaitu dengan memilih secara sengaja sampel yang akan diteliti sebagai responden. Responden yang dipilih berasal dari nasabah KUR yaitu sebanyak 88 orang. Penelitian dengan purposive sampling ini digunakan dalam penilaian tingkat kepuasan nasabah KUR Bank Rakyat Indonesia (BRI) Unit Tomohon Utara Kota Tomohon.

\section{Konsep Pengukuran Variabel}

Adapun variabel yang diteliti terhadap

Bank Rakyat Indonesia (BRI) Unit Tomohon

Utara Kota Tomohon adalah :

\section{A. Analisis 7P \\ 1. Product}

Kualitas KUR. Segala sesuatu yang dapat ditawarkan pihak bank untuk diperhatikan, diminta, dicari, dibeli, digunakan yang dapat memenuhi keinginan dan kebutuhan.

- Penentuan program KUR BRI

- Prinsip dasar pemberian KUR

- Sasaran KUR

- Kriteria nasabah KUR

- Sektor ekonomi usaha

- Pemberian pelayanan atau jasa kepada nasabah KUR.

\section{Price}

Penetapan harga KUR dalam hal tingkat bunga (suku bunga). Jumlah yang ditagih atas suatu produk KUR atau jumlah semua nilai yang diberikan oleh pelanggan untuk mendapatkan keuntungan dan memiliki atau menggunakan suatu produk KUR atau jasa (jangka waktu pembayaran, biaya administrasi, pola angsuran, denda dari nasabah, batas maks/min pemberian KUR).

\section{Place}

Tempat yang strategis \& sasaran dimana produk KUR dijual meliputi nasabah dan tempat. UMKM biasa diambil ke unit yang ada di desadesa.

a. Nasabah mendatangi pemberi jasa KUR (Perusahaan Jasa) di Bank Rakyat Indonesia (BRI) Unit Tomohon Utara Kota Tomohon. b. Pemberi jasa KUR mendatangi nasabah di Bank Rakyat Indonesia (BRI) Unit Tomohon Utara Kota Tomohon.

c. Pemberi jasa KUR nasabah tidak bertemu secara langsung. Berinteraksi melelui sarana komunikasi tertentu seperti telepon, komputer atau surat. Dalam hal ini, lokasi menjadi kurang penting selama komunikasi kedua pihak terlaksana.

\section{Promotion}

Bagaimana cara membuat ketertarikan kepada nasabah KUR, Kantor Unit Bank Rakyat Indonesia (BRI) Tomohon Utara yang menarik nasabah dan cara penyampaian informasi dalam strategi pemasaran KUR. Dalam periklanan penjualan personal, promosi penjualan hubungan masyarakat di Bank Rakyat Indonesia (BRI) Unit Tomohon Utara Kota Tomohon.

\section{People}

Semua pelaku yang memainkan peranan dalam penyajian KUR sehingga dapat mempengaruhi persepsi nasabah dalam hal ini adalah pegawai bank dan nasabah. Perilaku orangorang yang terlibat langsung ini sangat penting dalam mempengaruhi mutu dari KUR yang ditawarkan dan image dari bank yang bersangkutan dan hal yang diukur (manajemen bank meciptakan suasana yang menyenangkan, karyawan menangani nasabah, memperhatikan kepentingan nasabah, karyawan yang siap merespon nasabah, ketelitian karyawan, kesopanan karyawan, sambutan yang baik dari karyawan Bank Rakyat Indonesia (BRI) Unit Tomohon Utara Kota Tomohon.

\section{Physical Evidence}

Bukti fisik merupakan wujud nyata yang ditawarkan kepada nasabah ataupun calon nasabah yang dimiliki oleh Bank Rakyat Indonesia (BRI) Unit Tomohon Utara Kota Tomohon. (tempat dari bank yang menarik, brosur, banners, baliho, internet, perabotan, seragam dari karyawan, kartu nama, penataan ruangan/gedung, kendaraan operasional dan lain sebagainya).

\section{Process}

Proses merupakan gabungan semua aktivitas. Bagaimana cara Bank Rakyat Indonesia (BRI) Unit Tomohon Utara Kota Tomohon melayani permintaan tiap nasabah KUR. Mulai dari nasabah tersebut mendatangi pihak bank 
hingga akhirnya mereka mendapatkan apa yang mereka inginkan atau bagaimana nasabah menerima KUR. 7 (tujuh) prinsip ini yaitu: product, price, place, promotion, people, physical evidence dan process merupakan unsur-unsur yang saling berkaitan (pelayanan yang diberikan pada nasabah, citra perusahaan dimata nasabah, jaringan pemasaran langsung kepada nasabah, daya minat terhadap KUR, persaingan usaha yang dihadapi, menemui kendala/ risiko saat proses KUR, ketertarikan nasabah, jaminan untuk mendapatkan KUR, strategi Bank Rakyat Indonesia (BRI) Unit Tomohon Utara Kota Tomohon, proses dari input menjadi output produk KUR.

\section{Metode Analisis Data}

Dalam penelitian ini metode analisis data yang digunakan adalah analisis data deskriptif yaitu untuk menggambarkan Persepsi Nasabah Terhadap Penerapan 7P Dalam Program. Untuk mengetahui tentang persepsi dari nasabah Penerapan 7P Dalam Program KUR Bank Rakyat Indonesia (BRI) Unit Tomohon Utara Kota Tomohon, digunakan skala likert.

\section{Skala Likert}

Skala likert digunakan untuk mengukur sikap, pendapat dan persepsi seseorang atau kelompok orang tentang fenomena seseorang, Soegiyono (1996) dalam Sunyoto (2014). Dalam skala likert, maka variabel yang akan di ukur dijabarkan menjadi indikator variabel. Kemudian indikator tersebut dijadikan sebagai titik tolak untuk menyusun item - item instrument yang dapat berupa pernyataan - pernyataan. 88 orang (nasabah KUR). Jawaban setiap instrument yang menggunakan skala likert, yang berupa kata kata, antara lain :

$$
\begin{array}{ll}
\text { SS } & =\text { Sangat Setuju } \\
\text { S } & =\text { Setuju } \\
\text { CS } & =\text { Cukup Setuju } \\
\text { TS } & =\text { Tidak Setuju } \\
\text { STS } & =\text { Sangat Tidak Setuju }
\end{array}
$$

Bila :

SS diberi skor $=5$

$\mathrm{S}$ diberi skor $=4$

CS diberi skor $=3$

TS diberi skor $=2$

STS diberi skor $=1$

Dengan cara perhitungan skor masing - masing peryataaan bagi nasabah :

Jumlah skor tiap kriteria = capaian skor $\mathrm{X}$ jumlah responden.

$$
\begin{aligned}
& \text { S5 }=5 \times 88=440 \\
& \text { S4 }=4 \times 88=352 \\
& \text { S3 }=3 \times 88=264 \\
& \text { S2 }=2 \times 88=176 \\
& \text { S1 }=1 \times 88=88
\end{aligned}
$$

Jumlah skor ideal untuk setiap pertanyaan (skor tertinggi) $=440$

Jumlah skor terendah $=88$

Cara perhitungan skor keseluruhan untuk mengetahui kepuasan nasabah :

Jumlah skor seluruh kriterium = capaian jumlah skor $\mathrm{x}$ jumlah responden $\mathrm{x}$ instrumen pertanyaan Untuk :

$\mathrm{S} 5=5 \times 88 \times 24=10560$

$\mathrm{S} 4=4 \times 88 \times 24=8448$

$\mathrm{S} 3=3 \times 88 \times 24=6336$

$\mathrm{S} 2=2 \times 88 \times 24=4224$

$\mathrm{S} 1=1 \mathrm{X} 88 \times 24=2112$

Jumlah skor ideal untuk keseluruhan pertanyaan $=$ 10560 (tinggi)

Jumlah skor rendah $=2112$

Analisis data yang digunakan merupakan analisis deskriptif yang di analisis dengan menggunakan skala pengukuran Likert Scale. Adalah sebagai berikut :

$$
\begin{aligned}
& \text { Tingkat kepuasan nasabah } \\
& =\frac{\text { Jumlah Skor Hasil Pengumpulan Data }}{\text { Iumlah skor ideal (tertinggi) }} \times 100 \% \\
& \text { Dengan interprestasi nilai : } \\
& \begin{array}{|cccccc|}
\hline & 20 \% & 40 \% & 60 \% & 80 \% & 100 \% \\
& & & & & \\
\hline
\end{array} \\
& \begin{array}{lllll}
\text { STS } & \text { TS } & \text { CS } & \text { S } & \text { SS }
\end{array}
\end{aligned}
$$

Keterangan kriteria interpretasi skor kepuasan nasabah :

$$
\begin{array}{ll}
\text { Angka 0\%- 20\% } & =\text { Sangat Tidak Setuju } \\
\text { Angka 20\%-40\% } & =\text { Tidak Setuju } \\
\text { Angka 40\%-60\% } & =\text { Cukup Setuju } \\
\text { Angka 60\% }-80 \% & =\text { Setuju } \\
\text { Angka } 80 \%-100 \% & =\text { Sangat Setuju }
\end{array}
$$

\section{HASIL DAN PEMBAHASAN}

\section{Deskripsi Umum Tempat Penelitian}

Bank Rakyat Indonesia adalah salah satu bank milik pemerintah yang terbesar di Indonesia. Pada awalnya Bank Rakyat Indonesia (BRI) didirikan di Purwokerto Jawa Tengah oleh Raden Bei Aria Wiraatmadja. Lembaga tersebut berdiri tanggal 16 Desember 1895, yang kemudian dijadikan sebagai hari kelahiran BRI. Sejak 1 
Agustus 1992 berdasarkan Undang - Undang perbankan No 7 tahun 1992 dan peraturan pemerintah RI No 21 tahun `1992 status BRI berubah menjadi perseroan terbatas. Kepemilikan BRI saat itu masih $100 \%$ di tengah pemerintah RI. Pada tahun 2003, pemerintah Indonesia memutuskan menjual 30\% saham bank ini, sehingga menjadi perusahaan publik dengan nama resmi PT. Bank Rakyat Indonesia (Persero) Tbk yang masih digunakan sampai dengan saat ini. Pada saat ini saya mengambil tempat penelitian pada kantor Bank Rakyat Indonesia (BRI) Unit Tomohon Utara Kota Tomohon, yang beralamatkan Jln. Kakaskasen, Talete Dua, Tomohon Tengah, Kota Tomohon, Sulawesi Utara. Kepala Unit Bank BRI Unit Tomohon Utara yaitu Devi Ngala, dengan karyawan KUR berjumlah 4 orang.

\section{Kredit Usaha Rakyat (KUR)}

KUR mikro dalam hal pengajuan pinjaman dimana dalam pengajuan KUR mikro bisa dimungkinkan tanpa agunan. Terlihat pada besar suku bunga serta plafond KUR dimana suku bunga pinjaman ini cukup ringan yakni $9 \%$ per tahun dan plafond pinjaman KUR mikro s.d Rp 25 juta per debitur. Penetapan besar suku bunga KUR yang dilakukan oleh BRI menjadi suatu bukti bahwa perbankan ini sangat konsekwen atas tugas serta amanat yang diberikaan oleh pemerintah. Jenis pendanaan ini hanya boleh dipergunakan sebagai pengembangan atau modal usaha. Dengan kata lain pengajuan KUR BRI tidak diperbolehkan untuk keperluan lain. Hal ini karena KUR merupakan program pemerintah dalam mengupayakan pendanaan terhadap UMKM serta berbagai kalangan masyarakan yang berhak atas pinjaman tersebut. Siapa saja berhak mengajuakan kredit dalam hal usaha yang dijalankan produktif dan layak. KUR BRI dapat dilayani di seluruh Unit Kerja Bank Rakyat Indonesia (BRI) yang tersebar di seluruh Indonesia. Syaraat calon debitur : 1) Individu (perorangan) yang melakukan usaha produktif dan layak, 2) Telah melakukan usaha secara aktif minimal 6 bulan, 3) Tidak sedang menerima kredit dari perbankan kecuali kredit konsumtif seperti KPR, KKB, Kartu Kredit dan persyaratan administras, 4) Identitas berupa KTP, Kartu Keluarga (KK) dan Surat Ijin Usaha. Ketentuan dan syarat kredit : Besar kredit maksimal sebesar Rp. 25 juta per debitur. Jenis kredit : Kredit modal Kerja (KMK) jangka waktu maksimal 3 tahun dan Kredit Investasi (KI) jangka waktu atau setara $0,41 \%$ flat per bulan. NPL (Non Performing Loan) yang memiliki pengaruh terhadap bank, kredit macet inilah yang menyebabkan angka rasio persentase NPL meningkat drastis dan NPL yang terdapat di Bank BRI Unit Tomohon Utara Kota Tomohon adalah sebesar 2,46/tahun dari total kredit yang disalurkan. Penelitian ini bertujuan untuk mengetahui Persepsi Nasabah KUR Bank Rakyat Indonesia (BRI) Unit Tomohon Utara Kota Tomohon ditinjau dari Penerapan 7P (Markteing Mix). Dianalisis menggunakan skala likert.

\section{Karakteristik Responden}

Jumlah responden yang diambil dalam penelitian ini berjumlah 88 responden diambil dari 719 nasabah kredit usaha rakyat (KUR) Bank Rakyat Indonesia Unit Tomohon Utara Kota Tomohon. Penyajian data mengenai identitas responden disini, yaitu untuk memberikan gambaran tentang keadaan diri pada responden. Adapun gambaran tentang responden yang telah menjadi sampel dalam penelitian ini di klarifikasikan berdasarkan Jenis Kelamin, Umur, Tingkat Pendidikan. Berikut ini akan dibahas mengenai kondisi dari masing - masing klasifikasi responden.

\section{Umur Nasabah}

Setiap nasabah Bank BRI sudah pasti tidak sama, demikian juga dengan umur dari masing - masing nasabah, berikut adalah variasi umur dari tiap nasabah. Tabel 1 menunjukkan bahwa jumlah responden terbanyak pada umur dari 41- 47 tahun dengan jumlah 62 nasabah dengan persentasi sebesar $70 \%$ sedangkan jumlah sampel dengan tingkatan umur terendah pada iterval $31-40$ tahun dengan jumlah nasabah 26 nasabah dengan persentasi $30 \%$.

Tabel 1. Umur Nasabah

\begin{tabular}{llll}
\hline No & $\begin{array}{l}\text { Umur } \\
\text { (tahun) }\end{array}$ & $\begin{array}{l}\text { Jumlah } \\
\text { Nasabah }\end{array}$ & $\begin{array}{c}\text { Presentasi } \\
(\%)\end{array}$ \\
\hline 1 & $31-40$ & 26 & 30 \\
2 & $41-47$ & 62 & 70 \\
\hline & Jumlah & 88 & 100 \\
\hline
\end{tabular}

Sumber : Diolah dari data primer

\section{Tingkat Pendidikan}

Tingkat pendidikan dari masing - masing orang berbeda, begitu juga dengan tingkat pendidikan dari masing - masing nasabah yang mengambil KUR Bank Rakyat Indonesia (BRI) Unit Tomohon Utara Kota Tomohon. Tabel 2 
menunjukan bahwa tingkat pendidikan responden yang terbanyak yaitu pada tingkat pendidikan SMA dengan jumlah 66 orang dengan persentasi $75 \%$. Sedangkan tingkat pendidikan responden yang paling sedikit dengan tingkat pendidikan SMP dengan jumlah 22 orang dengan persentasi $25 \%$.

\section{Tabel 2 Tingkat Pendidikan}

\begin{tabular}{llll}
\hline No & $\begin{array}{l}\text { Tingkat } \\
\text { pendidikan }\end{array}$ & $\begin{array}{l}\text { Jumlah } \\
\text { Nasabah }\end{array}$ & $\begin{array}{l}\text { Persentasi } \\
(\%)\end{array}$ \\
\hline 1 & SMP & 22 & 25 \\
2 & SMA & 66 & 75 \\
\hline & Jumlah & 88 & 100
\end{tabular}

Sumber: Diolah dari data primer

\section{Jenis Kelamin}

Tabel 3 menunjukkan bahwa jenis kelamin dari nasabah KUR Bank Rakyat Indonesia (BRI) Unit Tomohon Utara Kota Tomohon. Sebagian besar responden nasabah KUR Bank Rakyat Indonesia (BRI) Unit Tomohon Utara Kota Tomohon adalah laki-laki dengan jumlah 57 orang dengan persentasi $65 \%$ sedangkan perempuan dengan jumlah 31 orang dengan persentasi $35 \%$.

Tabel 3 Jenis Kelamin

\begin{tabular}{llll}
\hline No & Jenis kelamin & $\begin{array}{l}\text { Jumlah } \\
\text { Nasabah }\end{array}$ & $\begin{array}{l}\text { Presentasi } \\
(\%)\end{array}$ \\
\hline 1 & Laki - laki & 57 & 65 \\
2 & Perempuan & 31 & 35 \\
\hline & Jumlah & 88 & 100 \\
\hline
\end{tabular}

Sumber: Diolah dari data primer

\section{Persepsi Nasabah Terhadap 7P (Marketing Mix)}

Pemasaran KUR yang dilakukan oleh Bank Rakyat Indonesia (BRI) Unit Tomohon Utara Kota Tomohon kepada nasabah KUR, dilihat dari 7 aspek. Pengukuran kinerja nasabah menunjukkan penilaian nasabah terhadap pelayanan KUR dalam memenuhi kebutuhan dan keinginan terhadap jenis-jenis KUR yang ditawarkan. Dalam penelitian ini aspek 7P (Marketing Mix) dalam perspektif nasabah KUR BRI Unit Tomohon Utara yaitu tingkat kepuasan nasabah. Pengukuran kinerja terhadap tingkat kepuasan nasabah sangat diperlukan untuk mengetahui persepsi (sikap dan tindakan) nasabah terhadap pelayanan yang diberikan Bank Rakyat Indonesia (BRI) Unit Tomohon Utara kota Tomohon. Dalam penelitian ini tingkat kepuasan nasabah dalam pemasaran KUR yang diukur adalah menggunakan 7P (Marketing Mix) yaitu : Product, Price, Place, Promotion, People, Physical Evidence, Process. Pemasaran KUR Bank Rakyat Indonesia (BRI) Unit Tomohon Utaar Kota Tomohon dilihat dari pengukuran tingkat kepuasan nasabah yaitu sebanyak 88 responden terdiri dari 31 perempuan dan 57 laki-laki, yang rata-rata berusia antara 30-47 Tahun. Dengan tingkat pendidikan 66 orang SMA, 22 orang SMP.

\section{Product}

Product (Produk) meliputi Penentuan program KUR BRI, prinsip dasar pemberian KUR, sasaran KUR, kriteria, nasabah sektor ekonomi usaha, pelayanan karyawan kepada nasabah KUR. Pengukuran kepuasan nasabah KUR dilihat dari kualitas produknya adalah untuk jenis usaha yang dikelolah oleh nasabah yang bersifat produktif.

\section{Kualitas KUR Bank BRI Unit Tomohon Utara sesuai dengan kebutuhan nasabah}

Tabel 4 menunjukan bahwa Kualitas atau mutu disini merupakan tingkat baik buruknya atau derajat dari produk KUR Bank Rakyat Indonesia (BRI) Unit Tomohon Utara Kota Tomohon. Angka indeks persepsi nasabah mengenai Kualitas KUR Bank BRI Unit Tomohon Utara sesuai dengan kebutuhan nasabah yaitu : 392/440X $100=89.09 \%$, Sehingga interpretasi nilainya tergolong Sangat Setuju (SS), artinya bahwa Kualitas KUR Bank BRI Unit Tomohon Utara sesuai dengan kebutuhan nasabah sangat bagus dan pemasarannya adalah baik karena produknya (KUR) yang berkualitas.

\section{Bank rakyat Indonesia (BRI) Unit Tomohon Utara Kota Tomohon menangkap pangsa pasar/nasabah melalui produk yang ditawarkan}

Tabel 5 menunjukan bahwa pangsa pasar yang dimaksud adalah nasabah KUR. Cara perusahaan menangkap pangsa pasar/nasabah melalui produk KUR yang ditawarkan. Angka indeks persepsi nasabah mengenai Kualitas KUR Bank BRI Unit Tomohon Utara sesuai dengan kebutuhan nasabah yaitu : 376/440X $100=85.45$ $\%$, Sehingga interpretasi nilainya tergolong Sangat Setuju (SS), aritnya bahwa perusahaan menangkap pangsa pasar/nasabah melalui produk yang ditawarkan sangat setuju terhadap pemasaran KUR Bank Rakyat Indonesia (BRI) Unit Tomohon Utara Kota Tomohon. 
Tabel 4. Kualitas KUR Bank Rakyat Indonesia (BRI) Unit Tomohon Utara Kota Tomohon sesuai dengan kebutuhan nasabah

\begin{tabular}{lllll}
\hline Alternatif Jawaban & Alternatif Skor & $\begin{array}{c}\text { Jumlah Responden } \\
\text { (orang) }\end{array}$ & $\begin{array}{c}\text { Peresentasi } \\
\text { Responden (\%) }\end{array}$ & Total Skor \\
\hline Sangat Setuju & 5 & 40 & 45.45 & 200 \\
Setuju & 4 & 48 & 54.55 & 192 \\
Cukup Setuju & 3 & - & - & - \\
Tidak Setuju & 2 & - & - & - \\
Sangat Tidak Setuju & 1 & - & - & 392 \\
\hline Total & & 88 & 100 & \\
\hline
\end{tabular}

Sumber: Diolah dari data primer

Tabel 5. Bank Rakyat Indonesia (BRI) Unit Tomohon Utara Kota Tomohon menangkap pangsa pasar/nasabah melalui produk yang ditawarkan

\begin{tabular}{lllll}
\hline Alternatif Jawaban & $\begin{array}{c}\text { Alternatif } \\
\text { Skor }\end{array}$ & $\begin{array}{c}\text { Jumlah Responden } \\
\text { (orang) }\end{array}$ & $\begin{array}{l}\text { Peresentasi } \\
\text { Responden }(\%)\end{array}$ & Total Skor \\
\hline Sangat Setuju & 5 & 36 & 40.91 & 180 \\
Setuju & 4 & 41 & 46.59 & 164 \\
Cukup Setuju & 3 & 10 & 11.36 & 30 \\
Tidak Setuju & 2 & 1 & 1.14 & 2 \\
Sangat Tidak Setuju & 1 & 0 & - & 0 \\
\hline Total & & 88 & 100 & 376
\end{tabular}

Sumber: Diolah dari data primer

Kriteria mendapatkan KUR Bank Rakyat Indonesia (BRI) Unit Tomohon Utara Kota Tomohon tidak sulit

Tabel 6 menunjukan bahwa Kriteria disini merupakan ukuran yang menjadi dasar penialian untuk mendapatkan KUR Bank Rakyat Indonesia (BRI) Unit Tomohon Utara Kota Tomohon dengan pernyataan bahwa tidak sulit. . Angka indeks persepsi nasabah terhadap pemasaran KUR, mengenai Kualitas KUR Bank Rakyat Indonesia (BRI) Unit Tomohon Utara sesuai dengan kebutuhan nasabah yaitu : 383/440X $100=87.07 \%$, sehingga interpretasi nilainya tergolong sangat setuju (SS), kriteria untuk mendapatkan KUR di Bank BRI Unit Tomohon Utara tidak sulit.

\section{Price}

Price menyangkut harga/suku Bunga yang diberikan pihak Bank Rakyat Indonesia BRI Unit Tomohon Utara ke pihak nasabah KUR.

Bank Rakyat Indonesia (BRI) Unit Tomohon Utara tidak memberikan biaya administrasi yang tinggi kepada nasabah

Tabel 7 menunjukan bahwa biaya administrasi yang dimaksudkan disini merupakan baiaya yang di bebankan kepada nasabah untuk mendapatkan KUR. Angka indeks persepsi nasabah mengenai pemasaran KUR yakni Bank Rakyat Indonesia (BRI) Unit Tomohon Utara tidak memberikan biaya administrasi yang tinggi ke nasabah yaitu : 383/440X $100=86.81 \%$, Sehingga interpretasi nilainya tergolong Sangat Setuju (SS).

Suku bunga yang diberikan Bank Rakyat Indonesia (BRI) Unit Tomohon Utara Kota Tomohon kepada nasabah tidak terlalu tinggi

Tabel 8 menunjukan bahwa suku bunga yang dimaksud adalah nilai dari pinjaman yang diberikan oleh pihak Bank Rakyat Indonesia (BRI) Unit Tomohon Utara kepada nasabah KUR. Angka indeks persepsi nasabah mengenai Suku bunga yang diberikan Bank BRI Unit Tomohon Utara ke nasabah tidak terlalu tinggi yaitu : 382/440X $100=$ $86.81 \%$, Sehingga interpretasi nilainya tergolong Sangat Setuju (SS). Ini menunjukan Suku bunga yang diberikan Bank BRI Unit Tomohon Utara ke nasabah tidak terlalu tinggi.

Jangka waktu yang diberikan Bank Rakyat Indonesia (BRI) Unit Tomohon Utara Kota Tomohon kepada nasabah untuk membayar dapat dijangkau nasabah.

Tabel 9 menunjukan bahwa jangka waktu yang dimaksud merupakan jatuh tempo dari KUR Bank Rakyat Indonesia (BRI) Unit Tomohon Utara dapat dijangkau oleh nasabah KUR. Angka indeks persepsi nasabah mengenai Suku bunga yang diberikan Bank Rakyat Indonesia (BRI) Unit Tomohon Utara Kota Tomohon ke nasabah tidak terlalu tinggi yaitu : 316/440X $100=71.81 \%$, Sehingga interpretasi nilainya tergolong Setuju (S). 
Tabel 6. Kriteria untuk mendapatkan KUR Bank Rakyat Indonesia (BRI) Unit Tomohon Utara Kota Tomohon tidak sulit

\begin{tabular}{lcccc}
\hline Alternatif Jawaban & $\begin{array}{c}\text { Alternatif } \\
\text { Skor }\end{array}$ & $\begin{array}{c}\text { Jumlah Responden } \\
\text { (orang) }\end{array}$ & $\begin{array}{c}\text { Peresentasi Responden } \\
(\%)\end{array}$ & Total Skor \\
\hline Sangat Setuju & 5 & 39 & 44.32 & 195 \\
Setuju & 4 & 41 & 46.59 & 164 \\
Cukup Setuju & 3 & 8 & 9.09 & 24 \\
Tidak Setuju & 2 & - & - & - \\
Sangat Tidak Setuju & 1 & - & 100 & 383 \\
\hline Total & & 88 & & - \\
\hline
\end{tabular}

Sumber: Diolah dari data primer

Tabel 7. Bank Rakyat Indonesia (BRI) Unit Tomohon Utara tidak memberikan biaya administrasi yang tinggi ke nasabah

\begin{tabular}{lcccc}
\hline Alternatif Jawaban & $\begin{array}{c}\text { Alternatif } \\
\text { Skor }\end{array}$ & $\begin{array}{c}\text { Jumlah Responden } \\
\text { (orang) }\end{array}$ & $\begin{array}{c}\text { Peresentasi Responden } \\
(\%)\end{array}$ & Total Skor \\
\hline Sangat Setuju & 5 & 37 & 42.05 & 195 \\
Setuju & 4 & 44 & 50.00 & 176 \\
Cukup Setuju & 3 & 7 & 7.95 & 21 \\
Tidak Setuju & 2 & - & - & - \\
Sangat Tidak Setuju & 1 & - & 100 & 382 \\
\hline Total & & 88 & & - \\
\hline
\end{tabular}

Sumber: Diolah dari data primer

Tabel 8. Suku bunga yang diberikan Bank Rakyat Indonesia (BRI) Unit Tomohon Utara Kota Tomohon kepada nasabah tidak terlalu tinggi

\begin{tabular}{lcccc}
\hline Alternatif Jawaban & $\begin{array}{c}\text { Alternatif } \\
\text { Skor }\end{array}$ & $\begin{array}{c}\text { Jumlah Responden } \\
\text { (orang) }\end{array}$ & $\begin{array}{c}\text { Peresentasi Responden } \\
(\%)\end{array}$ & $\begin{array}{c}\text { Total Skor } \\
\text { Sangat Setuju }\end{array}$ \\
Setuju & 4 & 39 & 44.32 & 195 \\
Cukup Setuju & 3 & 41 & 46.59 & 164 \\
Tidak Setuju & 2 & 7 & 7.95 & 21 \\
Sangat Tidak Setuju & 1 & 1 & 1.14 & - \\
\hline Total & & - & 100 & 382
\end{tabular}

Sumber: Diolah dari data primer

Tabel 9. Jangka waktu yang diberikan Bank BRI Unit Tomohon Utara kepada nasabah untuk membayar dapat dijangkau nasabah.

\begin{tabular}{lcccc}
\hline Alternatif jawaban & $\begin{array}{c}\text { Alternatif } \\
\text { Skor }\end{array}$ & $\begin{array}{c}\text { Jumlah Responden } \\
\text { (orang) }\end{array}$ & $\begin{array}{c}\text { Peresentasi Responden } \\
(\%)\end{array}$ & Total Skor \\
\hline Sangat Setuju & 5 & 9 & 10.23 & 45 \\
Setuju & 4 & 37 & 42.05 & 148 \\
Cukup Setuju & 3 & 39 & 44.32 & 117 \\
Tidak Setuju & 2 & 3 & 3.41 & 6 \\
Sangat Tidak Setuju & 1 & - & - & - \\
\hline Total & & 88 & 100 & 316
\end{tabular}

Sumber: Diolah dari data primer 


\section{Denda bagi nasabah yang terlambat} membayar dapat dijangkau

Tabel 10 menunjukan bahwa denda yang dimaksud disini adalah biaya yang dibebankan kepada pihak nasabah KUR Bank Rakyat Indonesia (BRI) Unit Tomohon Utara Kota Tomohon dapat dijangkau oleh nasabah itu sendiri. Angka indeks persepsi nasabah mengenai Denda bagi nasabah yang terlambat membayar dapat dijangkau tidak terlalu tinggi yaitu : 382/440X $100=86.81 \%$, Sehingga interpretasi nilainya tergolong Setuju (S). Ini menunjukan denda bagi nasabah yang terlambat membayar dapat dijangkau nasabah.

Batas minimal /maksimal pemberian KUR Bank Rakyat Indonesia (BRI) Unit Tomohon Utara Kota Tomohon memenuhi kebutuhan usaha dari nasabah

Tabel 11 menunjukan bahwa batas yang diberikan oleh pihak Bank Rakyat Indonesia (BRI) Unit Tomohon Utara Kota Tomohon. Batas minimal/maksimal pemberian KUR. Angka indeks persepsi nasabah mengenai Batas minimal /maksimal pemberian KUR Bank Rakyat Indonesia (BRI) Unit Tomohon Utara Kota Tomohon memenuhi kebutuhan usaha dari nasabah tidak terlalu tinggi yaitu : 390/440X $100=88.63 \%$, Sehingga interpretasi nilainya tergolong Setuju (S). Ini menunjukan Batas minimal /maksimal pemberian KUR Bank BRI Unit Tomohon Utara memenuhi kebutuhan usaha dari nasabah.

\section{Place}

Nasabah mendatangi pihak Bank Rakyat Indonesia (BRI) Unit Tomohon Utara Kota Tomohon, pihak bank mendatangi nasabah KUR Bank Rakyat Indonesia (BRI) Unit Tomohon Utara Kota Tomohon, pihak bank dan nasabah tidak bertemu secara langsung. Berinteraksi melelui sarana komunikasi tertentu seperti telepon, komputer atau surat.

\section{Posisi lokasi Bank Rakyat Indonesia (BRI) Unit Tomohon Utara Kota Tomohon dapat dijangkau}

Tabel 12 menunjukan bahwa posisi lokasi yang dimaksudkan disini merupakan posisi lokasi dari Bank Rakyat Indonesia (BRI) Unit Tomohon Utara Kota Tomohon dapat dijangkau oleh pihak nasabah. Posisi lokasi dapat menentukan sukses tidaknya suatu usaha khususnya pemberian Kredit Usaha Rakyat yang tujuannya dapat tersalurkan dengan baik kepada pihak nasabah dan dapat membantu usaha yang dijalankan oleh nasabah KUR Angka indeks persepsi nasabah terhadap pemaasaran KUR, mengenai posisi lokasi Bank Rakyat Indonesia (BRI) Unit Tomohon Utara Kota Tomohon dapat dijangkau yaitu : 320/440X $100=72.72 \%$, Sehingga interpretasi nilainya tergolong Setuju (S). Ini menunjukan Posisi lokasi Bank BRI Unit Tomohon Utara dapat dijangkau.

Pihak Bank Rakyat Indonesia (BRI) Unit Tomohon Utara Kota Tomohon mudah untuk menjangkau nasabah

Tabel 13 menunjukan bahwa kemudahan dalam menjangkau nasabah sangat dibutuhkan oleh pihak bank dalam berlangsungnya pemberian KUR. Angka indeks persepsi nasabah mengenai pemasaran KUR, yakni Pihak Bank Rakyat Indonesia (BRI) Unit Tomohon mudah untuk menjangkau nasabah yaitu : $375 / 440 X 100=85,22 \%$, Sehingga interpretasi nilainya tergolong Sangat Setuju (SS). Ini menunjukan Pihak Bank BRI Unit Tomohon Utara Kota Tomohon mudah untuk menjangkau nasabah.

Lokasi/tempat Bank Rakyat Indonesia (BRI) Unit Tomohon Utara Kota Tomohon berpengaruh pada nasabah dalam memilih tempat untuk mendapatkan KUR.

Tabel 14 menunjukan bahwa usaha yang dapat dikatakan berjalan baik dapat dipengaruhi oleh posisi lokasi. Lokasi/tempat dari bank sangat berpengaruh pada nasabah dalam memilih tempat untuk mendapatkan KUR. Angka indeks persepsi nasabah mengenai pemasaran KUR, yakni Lokasi/tempat berpengaruh pada nasabah dalam memilih tempat untuk mendapatkan KUR yaitu $386 / 440 X 100=87.72 \%$, Sehingga interpretasi nilainya tergolong sangat Setuju (S). Ini menunjukan Lokasi/tempat dari Bank Rakyat Indonesia (BRI) Unit Tomohon Utara berpengaruh pada nasabah dalam memilih tempat untuk mendapatkan KUR. 
Tabel 10. Denda bagi nasabah yang terlambat membayar dapat dijangkau

\begin{tabular}{lcccc}
\hline Alternatif Jawaban & $\begin{array}{c}\text { Alternatif } \\
\text { Skor }\end{array}$ & $\begin{array}{c}\text { Jumlah Responden } \\
\text { (orang) }\end{array}$ & $\begin{array}{c}\text { Peresentasi Responden } \\
(\%)\end{array}$ & Total Skor \\
\hline Sangat Setuju & 5 & 39 & 44.32 & 195 \\
Setuju & 4 & 41 & 46.59 & 164 \\
Cukup Setuju & 3 & 7 & 7.95 & 21 \\
Tidak Setuju & 2 & 1 & 1.14 & 2 \\
Sangat Tidak Setuju & 1 & - & - & - \\
\hline Total & & 88 & 100 & 382 \\
\hline
\end{tabular}

Sumber: Diolah dari data primer

Tabel 11. Batas minimal /maksimal pemberian KUR Bank Rakyat Indonesia (BRI) Unit Tomohon Utara Kota Tomohon memenuhi kebutuhan usaha dari nasabah

\begin{tabular}{lcccc}
\hline Alternatif Jawaban & $\begin{array}{c}\text { Alternatif } \\
\text { Skor }\end{array}$ & $\begin{array}{c}\text { Jumlah Responden } \\
\text { (orang) }\end{array}$ & $\begin{array}{c}\text { Peresentasi Responden } \\
(\%)\end{array}$ & Total Skor \\
\hline Sangat Setuju & 5 & 39 & 44.32 & 195 \\
Setuju & 4 & 48 & 54.55 & 192 \\
Cukup Setuju & 3 & 1 & 1.14 & 3 \\
Tidak Setuju & 2 & - & - & - \\
Sangat Tidak Setuju & 1 & - & - & - \\
\hline Total & & 88 & 100 & 390 \\
\hline
\end{tabular}

Sumber: Diolah dari data primer

Tabel 12. Posisi lokasi Bank Rakyat Indonesia (BRI) Unit Tomohon Utara Kota Tomohon dapat dijangkau

\begin{tabular}{lcccc}
\hline Alternatif Jawaban & $\begin{array}{c}\text { Alternatif } \\
\text { Skor }\end{array}$ & $\begin{array}{c}\text { Jumlah Responden } \\
\text { (orang) }\end{array}$ & $\begin{array}{c}\text { Peresentasi Responden } \\
(\%)\end{array}$ & Total Skor \\
\hline Sangat Setuju & 5 & 9 & 10.23 & 45 \\
Setuju & 4 & 39 & 44.32 & 156 \\
Cukup Setuju & 3 & 39 & 44.32 & 117 \\
Tidak Setuju & 2 & 1 & 1.14 & 2 \\
Sangat Tidak Setuju & 1 & - & - & - \\
\hline Total & & 88 & 100 & 320 \\
\hline
\end{tabular}

Sumber: Diolah dari data primer

Tabel 13. Pihak Bank Rakyat Indonesia (BRI) Unit Tomohon Utara Kota Tomohon mudah untuk menjangkau nasabah

\begin{tabular}{lcccc}
\hline Alternatif Jawaban & $\begin{array}{c}\text { Alternatif } \\
\text { Skor }\end{array}$ & $\begin{array}{c}\text { Jumlah Responden } \\
\text { (orang) }\end{array}$ & $\begin{array}{c}\text { Peresentasi Responden } \\
(\%)\end{array}$ & Total Skor \\
\hline Sangat Setuju & 5 & 34 & 38.64 & 170 \\
Setuju & 4 & 43 & 48.86 & 172 \\
Cukup Setuju & 3 & 11 & 12.50 & 33 \\
Tidak Setuju & 2 & - & - & - \\
Sangat Tidak Setuju & 1 & - & 100 & 375 \\
\hline Total & & & &
\end{tabular}

Sumber: Diolah dari data primer

Tabel 14. Lokasi/tempat Bank Rakyat Indonesia (BRI) Unit Tomohon Utara Kota Tomohon berpengaruh pada nasabah dalam memilih tempat untuk mendapatkan KUR.

\begin{tabular}{lcccc}
\hline Alternatif Jawaban & $\begin{array}{c}\text { Alternatif } \\
\text { Skor }\end{array}$ & $\begin{array}{c}\text { Jumlah Responden } \\
\text { (orang) }\end{array}$ & $\begin{array}{c}\text { Peresentasi Responden } \\
(\%)\end{array}$ & Total Skor \\
\hline Sangat Setuju & 5 & 40 & 45.45 & 200 \\
Setuju & 4 & 42 & 47.73 & 168 \\
Cukup Setuju & 3 & 6 & 6.82 & 18 \\
Tidak Setuju & 2 & - & - & - \\
Sangat Tidak Setuju & 1 & - & - & 386 \\
\hline Total & & 88 & 100 & - \\
\hline
\end{tabular}

Sumber: Diolah dari data primer 


\section{Promotion}

promosi terdiri dari 2 cara yang dilakuakan Bank Rakyat Indonesia (BRI) Unit Tomohon Utara kota Tomohon terapkan yaitu promosi langsung (mengunjungi tempat tinggal/rumah calon nasabah) dan promosi secara tidak langsung (internet, media masa dan memasang spanduk-spanduk di pekan olahraga dan kegiatan lainnya).

\section{Promosi yang dilakukan Bank Rakyat Indonesia (BRI) Unit Tomohon Utara Kota Tomohon menarik nasabah KUR}

Tabel 15 promosi disini merupakan upaya pihak bank untuk memberitahukan atau menawarkan KUR dengan tujuan menarik nasabah KUR. Angka indeks persepsi nasabah mengenai pemasaran KUR terhadap promosi yang dilakukan Bank Rakyat Indonesia (BRI) Unit Tomohon Utara menarik nasabah KUR yaitu : 390/440X $100=88.64 \%$, Sehingga interpretasi nilainya tergolong Sangat Setuju (SS). Ini menunjukan Promosi yang dilakukan pihak bank menarik nasabah KUR.

Bank Rakyat Indonesia (BRI) Unit Tomohon Utara Kota Tomohon mempromosikan KUR secara langsung (membuat seminar,mengunjungi rumah nasabah) atau seacara tidak langsung (melalui media sosial,Koran,TV,Radio)

Tabel 16 menunjukan ketertarikan nasabah dalam memilih KUR Bank Rakyat Indonesia (BRI) Unit Tomohon Utara Kota Tomohon dipengaruhi dari bagaimana cara promosi yang dilakukan baik promosi secara langsung atau promosi secara tidak langsung. Angka indeks persepsi nasabah mengenai pemasaran KUR, yakni Bank Rakyat Indonesia (BRI) Unit Tomohon Utara Kota Tomhon mempromosikan KUR secara langsung (membuat seminar,mengunjungi rumah nasabah dll) atau seacara tidak langsung (melalui media sosial,Koran,TV,Radio dll) yaitu : 390/440X 100 $=88.64 \%$, Sehingga interpretasi nilainya tergolong Sangat Setuju (SS). Ini menunjukan promosi yang dilakukan pihak bank dapat menjangkau nasabah KUR.

\section{People}

Manajemen Bank Rakyat Indonesia (BRI) Unit Tomohon Utara Kota Tomohon meciptakan suasana yang menyenangkan, karyawan menangani nasabah, memperhatikan kepentingan nasabah, karyawan yang siap merespon nasabah, ketelitian karyawan, kesopanan karyawan, sambutan yang baik dari karyawan.

$\begin{array}{lll}\text { Karyawan Bank Rakyat Indonesia } & \text { (BRI) Unit } \\ \text { Tomohon Utara Kota Tomohon }\end{array}$ memperhatikan kepentingan nasabah

Tabel 17 menunjukan people yang dimaksudkan disini merupakan karyawan KUR (mantri KUR), dengan pernyataan karyawan Bank BRI Unit Tomohon Utara memperhatikan kepentingan nasabah. Angka indeks persepsi nasabah mengenai pemasaran KUR, yakni karyawan Bank Rakyat Indonesia (BRI) Unit Tomohon Utara Kota Tomohon memperhatikan kepentingan nasabah yaitu : 383/440X $100=$ $87.04 \%$, Sehingga interpretasi nilainya tergolong Sangat Setuju (SS). Ini menunjukan Karyawan memperhatikan kepentingan nasabah

\section{Karyawan memberikan perlakuan yang sama kepada semua nasabah}

Tabel 18 menunjukan sbhwaetiap karyawan haruslah memberikan perlakuan yang sama kepada setiap nasabah yang datang agar nasabah semua merasa nyaman berada di Bank Rakyat Indonesia (BRI) Unit Tomohon Utara Kota Tomohon. Angka indeks persepsi nasabah mengenai pemasaran KUR, yakni karyawan memberikan perlakuan yang sama kepada semua nasabah yaitu : 380/440X $100=86.36 \%$, Sehingga interpretasi nilainya tergolong sangat Setuju (S). Ini menunjukan Karyawan memberikan perlakuan yang sama kepada semua nasabah.

Pihak Bank Rakyat Indonesia (BRI) Unit Tomohon Utara Kota Tomohon menyediakan layanan sesuai yang dijanjikan kepada nasabah

Tabel 19 menunjukan bahwa setiap nasabah pastilah memberikan penilaian kepada pelayanan yang diberikan oleh pihak bank dalam proses penyaluran KUR dan layanan sesuai yang dijanjikan kepada nasabah dibutuhkan oleh nasabah untuk meningkatkan rasa kepercayaan antara pihak Bank dan pihak nasabah. Angka indeks persepsi nasabah mengenai pemasaran KUR, yakni pihak Bank Rakyat Indonesia (BRI) Unit Tomohon Utara kota Tomohon menyediakan layanan sesuai yang dijanjikan kepada nasabah yaitu : 382/440X $100=$ $86.81 \%$, Sehingga interpretasi nilainya tergolong Sangat Setuju (SS). Ini menunjukan Pihak Bank BRI Unit Tomohon Utara menyediakan layanan sesuai yang dijanjikan kepada nasabah. 
Tabel 15. Promosi yang dilakukan Bank Rakyat Indonesia (BRI) Unit Tomohon Utara Kota Tomohon menarik nasabah KUR

\begin{tabular}{lcccc}
\hline Alternatif Jawaban & $\begin{array}{c}\text { Alternatif } \\
\text { Skor }\end{array}$ & $\begin{array}{c}\text { Jumlah Responden } \\
\text { (orang) }\end{array}$ & $\begin{array}{c}\text { Peresentasi Responden } \\
(\%)\end{array}$ & Total Skor \\
\hline Sangat Setuju & 5 & 43 & 48.86 & 215 \\
Setuju & 4 & 40 & 45.45 & 160 \\
Cukup Setuju & 3 & 5 & 5.68 & 15 \\
Tidak Setuju & 2 & - & - & - \\
Sangat Tidak Setuju & 1 & - & - & 390 \\
\hline Total & & 88 & 100 & - \\
\hline
\end{tabular}

Sumber: Diolah dari data primer

Tabel 16. Bank Rakyat Indonesia (BRI) Unit Tomohon Utara Kota Tomohon mempromosikan KUR secara langsung

\begin{tabular}{lcccc}
\hline Alternatif Jawaban & $\begin{array}{c}\text { Alternatif } \\
\text { Skor }\end{array}$ & $\begin{array}{c}\text { Jumlah Responden } \\
\text { (orang) }\end{array}$ & $\begin{array}{c}\text { Peresentasi Responden } \\
(\%)\end{array}$ & Total Skor \\
\hline Sangat Setuju & 5 & 40 & 45.45 & 200 \\
Setuju & 4 & 46 & 52.27 & 184 \\
Cukup Setuju & 3 & 2 & 2.27 & 6 \\
Tidak Setuju & 2 & - & - & - \\
Sangat Tidak Setuju & 1 & - & - & - \\
\hline Total & & 88 & 100 & 390 \\
\hline
\end{tabular}

Sumber: Diolah dari data primer

Tabel 17. Karyawan Bank Rakyat Indonesia (BRI) Unit Tomohon Utara Kota Tomohon memperhatikan kepentingan nasabah

\begin{tabular}{lcccc}
\hline Alternatif Jawaban & $\begin{array}{c}\text { Alternatf } \\
\text { Skor }\end{array}$ & $\begin{array}{c}\text { Jumlah Responden } \\
\text { (orang) }\end{array}$ & $\begin{array}{c}\text { Peresentasi Responden } \\
(\%)\end{array}$ & Total Skor \\
\hline Sangat Setuju & 5 & 38 & 43.18 & 190 \\
Setuju & 4 & 43 & 48.86 & 172 \\
Cukup Setuju & 3 & 7 & 7.95 & 21 \\
Tidak Setuju & 2 & - & - & - \\
Sangat Tidak Setuju & 1 & - & 100 & 383 \\
\hline Total & & 88 & & - \\
\hline
\end{tabular}

Sumber: Diolah dari data primer

Tabel 18 Karyawan memberikan perlakuan yang sama kepada semua nasabah

\begin{tabular}{lcccc}
\hline Alternatif Jawaban & $\begin{array}{c}\text { Alternatf } \\
\text { Skor }\end{array}$ & $\begin{array}{c}\text { Jumlah Responden } \\
\text { (orang) }\end{array}$ & $\begin{array}{c}\text { Peresentasi Responden } \\
(\%)\end{array}$ & Total Skor \\
\hline Sangat Setuju & 5 & 36 & 40.91 & 180 \\
Setuju & 4 & 44 & 50.00 & 176 \\
Cukup Setuju & 3 & 8 & 9.09 & 24 \\
Tidak Setuju & 2 & - & - & - \\
Sangat Tidak Setuju & 1 & - & - & - \\
\hline Total & & 88 & 100 & 380 \\
\hline
\end{tabular}

Sumber: Diolah dari data primer

Tabel 19. Pihak Bank Rakyat Indonesia (BRI) Unit Tomohon Utara Kota Tomohon menyediakan layanan sesuai yang dijanjikan kepada nasabah

\begin{tabular}{lcccc}
\hline Alternatif Jawaban & $\begin{array}{c}\text { Alternatf } \\
\text { Skor }\end{array}$ & $\begin{array}{c}\text { Jumlah Responden } \\
\text { (orang) }\end{array}$ & $\begin{array}{c}\text { Peresentasi Responden } \\
(\%)\end{array}$ & Total Skor \\
\hline Sangat Setuju & 5 & 39 & 44.32 & 195 \\
Setuju & 4 & 40 & 45.45 & 160 \\
Cukup Setuju & 3 & 9 & 10.23 & 27 \\
Tidak Setuju & 2 & - & - & - \\
Sangat Tidak Setuju & 1 & - & - & - \\
\hline Total & & 88 & 100 & 382 \\
\hline
\end{tabular}

Sumber: Diolah dari data primer 


\section{Physical Evidence}

Tempat yang menarik, brosur, banners, baliho, internet, perabotan, seragam dari karyawan, kartu nama, penataan ruangan/gedung, kendaraan operasional dan lain sebagainya

Kerapihan seragam yang digunakan karyawan Bank Rakyat Indonesia (BRI) Unit Tomohon Utara Kota Tomohon saat melayani nasabah

Tabel 20 menunjukan bahwa kerapihan seragam dalam proses penyaluran KUR harus diperhatikan oleh karyawan Bank Rakyat Indonesia (BRI) Unit Tomohon Utara Kota Tomohon saat melayani nasabah KUR. Angka indeks persepsi nasabah mengenai pemasaran KUR, yakni, kerapihan seragam yang digunakan karyawan Bank Rakyat Indonesia (BRI) Unit Tomohon Utara kota Tomohon saat melayani nasabah yaitu : 383/440X $100=87.06 \%$, Sehingga interpretasi nilainya tergolong Sangat Setuju (SS). Ini menunjukan Kerapihan seragam yang digunakan karyawan Bank BRI Unit Tomohon Utara saat melayani nasabah.

\section{Bank Rakyat Indonesia (BRI) Unit Tomohon} Utara Kota Tomohon menyediakan tempat parkir yang memadai

Tabel 21 menunjukan bahwa tempat parkir yang dimaksud adalah tempat parkir yang disediakan oleh pihak Bank BRI Unit Tomohon Utara Kota Tomohon. Angka indeks persepsi nasabah mengenai pemasaran KUR, terhadap Bank Rakyat Indonesia (BRI) Unit Tomohon Utara Kota Tomohon menyediakan tempat parkir yang memadai yaitu : $255 / 440 X$ $100=57.95 \%$, Sehingga interpretasi nilainya tergolong Cukup Setuju (CS). Ini menunjukan Bank Rakyat Indonesia (BRI) Unit Tomohon Utara Kota Tomohon menyediakan tempat parkir yang kurang memadai.

Adanya Dekorasi Yang Menarik, Kesejukan Ruang Tunggu, Kebersihan Gedung dan Kebersihan Toilet Bank Rakyat Indonesia (BRI) Unit Tomohon Utara Kota Tomohon

Tabel 22 menunjukan bahwa physical Evidence merupakan bukti fisik dari pihak bank seperti adannya dekorasi yang menarik, kesejukan ruang tunggu, kebersihan gedung dan kebersihan toilet Bank Rakyat Indonesia (BRI) Unit Tomohon Utara Kota Tomohon. Angka indeks persepsi nasabah mengenai pemasran KUR, yakni adanya dekorasi yang menarik, kesejukan ruang tunggu, kebersihan gedung dan kebersihan toilet di Bank BRI Unit Tomohon Utara yaitu : 383/440X $100=$ $87.04 \%$, Sehingga interpretasi nilainya tergolong Sangat Setuju (SS).

Adanya kendaraan operasional yang tersedia di Bank Rakyat Indonesia (BRI) Unit Tomohon Utara Kota Tomohon (Physical Evidence)

Tabel 23 menunjukan bahwa kendaraan operasional yang dimaksud merupakan kendaran kantor atau kendaraan Bank Rakyat Indonesia (BRI) Unit Tomohon Utara Kota Tomohon untuk menunjang penyaluran KUR. Angka indeks persepsi nasabah mengenai pemasraan KUR, yakni adanya kendaraan operasional yang tersedia di Bank Rakyat Indonesia (BRI) Unit Tomohon Utara Kota Tomohon (Physical Evidence) yaitu : 386/440X $100=87.72 \%$, Sehingga interpretasi nilainya tergolong sangat setuju.

\section{Process}

Proses KUR dari Input menjadi Output. Apakah menemui kendala atau belum/tidak.

Pelayanan yang diberikan kepada nasabah baik

Tabel 24 menunjukan bahwa pelayanan yang baik dari pihak Bank Rakyat Indonesia (BRI) Unit Tomohon Utara Kota Tomohon sangat dibutuhkan oleh nasabah KUR agar nasabah senang berada disana. Angka indeks persepsi nasabah mengenai pemasaran KUR, yakni Pelayanan yang diberikan kepada nasabah baik yaitu : 382/440X $100=86.81 \%$, Sehingga interpretasi nilainya tergolong Sangat Setuju (SS). Ini menunjukan Pelayanan yang diberikan kepada nasabah baik. 
Tabel 20. Kerapihan seragam yang digunakan karyawan Bank BRI Unit Tomohon Utara saat melayani nasabah

\begin{tabular}{lcccc}
\hline \multicolumn{1}{c}{ Alternatif Jawaban } & $\begin{array}{c}\text { Alternatif } \\
\text { Skor }\end{array}$ & $\begin{array}{c}\text { Jumlah Responden } \\
\text { (orang) }\end{array}$ & $\begin{array}{c}\text { Peresentasi Responden } \\
(\%)\end{array}$ & Total Skor \\
\hline Sangat Setuju & 5 & 38 & 43.18 & 190 \\
Setuju & 4 & 43 & 48.86 & 172 \\
Cukup Setuju & 3 & 7 & 7.95 & 21 \\
Tidak Setuju & 2 & - & - & - \\
Sangat Tidak Setuju & 1 & - & 100 & 383 \\
\hline Total & & 88 & & - \\
\hline
\end{tabular}

Sumber: Diolah dari data primer

Tabel 21. Bank Rakyat Indonesia (BRI) Unit Tomohon Utara Kota Tomohon menyediakan tempat parkir yang memadai

\begin{tabular}{lcccc}
\hline Alternatif Jawaban & $\begin{array}{c}\text { Alternatif } \\
\text { Skor }\end{array}$ & $\begin{array}{c}\text { Jumlah Responden } \\
\text { (orang) }\end{array}$ & $\begin{array}{c}\text { Peresentasi Responden } \\
(\%)\end{array}$ & Total Skor \\
\hline Sangat Setuju & 5 & 1 & 1.14 & 5 \\
Setuju & 4 & 15 & 17.05 & 60 \\
Cukup Setuju & 3 & 46 & 52.27 & 138 \\
Tidak Setuju & 2 & 26 & 29.55 & 52 \\
Sangat Tidak Setuju & 1 & - & - & - \\
\hline Total & & 88 & & 255 \\
\hline Sumber: & & & &
\end{tabular}

Sumber: Diolah dari data primer

Tabel 22. Adanya dekorasi yang menarik, kesejukan ruang tunggu, kebersihan gedung dan kebersihan toilet Bank BRI Unit Tomohon Utara

\begin{tabular}{lcccc}
\hline Alternatif Jawaban & $\begin{array}{c}\text { Alternatif } \\
\text { Skor }\end{array}$ & $\begin{array}{c}\text { Jumlah Responden } \\
\text { (orang) }\end{array}$ & $\begin{array}{c}\text { Peresentasi Responden } \\
(\%)\end{array}$ & Total Skor \\
\hline Sangat Setuju & 5 & 40 & 45.45 & 200 \\
Setuju & 4 & 39 & 44.32 & 156 \\
Cukup Setuju & 3 & 9 & 10.23 & 27 \\
Tidak Setuju & 2 & - & - & - \\
Sangat Tidak Setuju & 1 & - & 100 & 383 \\
\hline Total & & 88 & & - \\
\hline
\end{tabular}

Sumber: Diolah dari data primer

Tabel 23. Adanya kendaraan operasional yang tersedia di Bank Rakyat Indonesia (BRI) Unit Tomohon Utara Kota Tomohon (Physical Evidence)

\begin{tabular}{lcccc}
\hline Alternatif Jawaban & $\begin{array}{c}\text { Alternatf } \\
\text { Skor }\end{array}$ & $\begin{array}{c}\text { Jumlah Responden } \\
\text { (orang) }\end{array}$ & $\begin{array}{c}\text { Peresentasi Responden } \\
(\%)\end{array}$ & Total Skor \\
\hline Sangat Setuju & 5 & 41 & 46.59 & 205 \\
Setuju & 4 & 40 & 45.45 & 160 \\
Cukup Setuju & 3 & 7 & 7.95 & 21 \\
Tidak Setuju & 2 & - & - & - \\
Sangat Tidak Setuju & 1 & - & - & 386 \\
\hline Total & & 88 & 100 & - \\
\hline
\end{tabular}

Sumber: Diolah dari data primer

Tabel 24. Pelayanan yang diberikan kepada nasabah baik

\begin{tabular}{lcccc}
\hline Alternatif Jawaban & $\begin{array}{c}\text { Alternatif } \\
\text { Skor }\end{array}$ & $\begin{array}{c}\text { Jumlah Responden } \\
\text { (orang) }\end{array}$ & $\begin{array}{c}\text { Peresentasi Responden } \\
(\%)\end{array}$ & Total Skor \\
\hline Sangat Setuju & 5 & 37 & 42.05 & 185 \\
Setuju & 4 & 44 & 50.00 & 176 \\
Cukup Setuju & 3 & 7 & 7.95 & 21 \\
Tidak Setuju & 2 & - & - & - \\
Sangat Tidak Setuju & 1 & - & 100 & - \\
\hline Total & & 88 & & 382 \\
\hline
\end{tabular}

Sumber: Diolah dari data primer 


\section{Adanya jaringan pemasaran yang langsung kepada nasabah}

Tabel 25 menunjukan bahwa jaringan pemasaran yang langsung kepada nasabah dapat mempengaruhi nasabah itu sendiri dalam memilih KUR Bank Rakyat Indonesia (BRI) Unit Tomohon Utara Kota Tomohon. Angka indeks persepsi nasabah mengenai pemasaran KUR, yakni adanya jaringan pemasaran yang langsung kepada sebagai nasabah yaitu : $383 / 440 X 100=87.04 \%$, Sehingga interpretasi nilainya tergolong sangat setuju. Ini menunjukan Adanya jaringan pemasaran yang langsung kepada sebagai nasabah.

Adanya jaminan yang harus disepakati untuk mendapatkan KUR Bank Rakyat Indonesia (BRI) Unit Tomohon Utara Kota Tomohon

Tabel 26 menunjukan bahwa kepercayaan merupakan hal yang sangat penting dalam penyaluran KUR Bank Rakyat Indonesia (BRI) Unit Tomohon Utara Kota Tomohon. Adanyan jaminan yang harus disepakati untuk mendapatkan KUR. Angka indeks persepsi nasabah pemasaran KUR, adanya jaminan yang harus disepakati untuk mendapatkan KUR Bank Rakyat Indonesia (BRI) Unit Tomohon Utara Kota
Tomohon yaitu : 381/440X $100=86.59 \%$, Sehingga interpretasi nilainya tergolong Sangat Setuju (SS). Ini menunjukan Adanya jaminan yang harus disepakati untuk mendapatkan KUR Bank Rakyat Indonesia (BRI) Unit Tomohon Utara Kota Tomohon.

Menjalankan suatu usaha tentu harus memikirkan prospek ke depan agar usaha berjalan dengan lancar, karena mengingat pesaing usaha yang ada.

Tabel 27 menunjukan bahwa usaha yang baik adalah usaha yang harus memikirkan prospek kedepan supaya usaha yang dijalankan berjalan baik sesuai yang diharapkan dalam hal ini adalah KUR Bank Rakyat Indonesia (BRI) Unit Tomohon Utara Kota Tomohon. Angka indeks persepsi nasabah mengenai pemasaran KUR, yakni untuk menjalankan suatu usaha tentu harus memikirkan prospek ke depan agar usaha berjalan dengan lancar, karena mengingat pesaing usaha yang ada.yaitu : 382/440X $100=86.82 \%$, Sehingga interpretasi nilainya tergolong Sangat Setuju (SS). Ini menunjukan Menjalankan suatu usaha tentu harus memikirkan prospek ke depan agar usaha berjalan dengan lancar, karena mengingat pesaing usaha yang ada untuk kemajuan usaha yang dijalankan.

Tabel 25 Adanya jaringan pemasaran yang langsung kepada nasabah

\begin{tabular}{lcccc}
\hline Alternatif jawaban & $\begin{array}{c}\text { Alternatif } \\
\text { Skor }\end{array}$ & $\begin{array}{c}\text { Jumlah Responden } \\
\text { (orang) }\end{array}$ & $\begin{array}{c}\text { Peresentasi Responden } \\
(\%)\end{array}$ & Total Skor \\
\hline Sangat Setuju & 5 & 38 & 43.18 & 190 \\
Setuju & 4 & 43 & 48.86 & 172 \\
Cukup Setuju & 3 & 7 & 7.95 & 21 \\
Tidak Setuju & 2 & - & - & - \\
Sangat Tidak Setuju & 1 & - & - & - \\
\hline Total & & 88 & 100 & 383 \\
\hline
\end{tabular}

Sumber: Diolah dari data primer

Tabel 26. Adanya jaminan yang harus disepakati untuk mendapatkan KUR Bank Rakyat Indonesia (BRI)

\begin{tabular}{lcccc}
\hline Alternatif Jawaban & $\begin{array}{c}\text { Alternatif } \\
\text { Skor }\end{array}$ & $\begin{array}{c}\text { Jumlah Responden } \\
\text { (orang) }\end{array}$ & $\begin{array}{c}\text { Peresentasi Responden } \\
(\%)\end{array}$ & Total Skor \\
\hline Sangat Setuju & 5 & 38 & 43.18 & 190 \\
Setuju & 4 & 41 & 46.59 & 164 \\
Cukup Setuju & 3 & 9 & 10.23 & 27 \\
Tidak Setuju & 2 & - & - & - \\
Sangat Tidak Setuju & 1 & - & - & - \\
\hline Total & & 88 & 100 & 381 \\
\hline
\end{tabular}

Sumber: Diolah dari data primer

Tabel 27. Menjalankan suatu usaha tentu harus memikirkan prospek ke depan agar usaha berjalan dengan lancar, karena mengingat pesaing usaha yang ada.

\begin{tabular}{lcccc}
\hline Alternatif Jawaban & $\begin{array}{c}\text { Alternatif } \\
\text { Skor }\end{array}$ & $\begin{array}{c}\text { Jumlah Responden } \\
\text { (orang) }\end{array}$ & $\begin{array}{c}\text { Peresentasi Responden } \\
(\%)\end{array}$ & Total Skor \\
\hline Sangat Setuju & 5 & 39 & 44.32 & 195 \\
Setuju & 4 & 40 & 45.45 & 160 \\
Cukup Setuju & 3 & 9 & 10.23 & 27 \\
Tidak Setuju & 2 & - & - & - \\
Sangat Tidak Setuju & 1 & - & - & - \\
\hline Total & & 88 & 100 & 382 \\
\hline
\end{tabular}

Sumber: Diolah dari data primer 
Rekapitulasi Indeks Persepsi Kepuasan Nasabah Pada Masing-masing Indikator (7P) Dan Interpretasi Hasil

Tabel 28 menunjukan bahwa penelitian mengukur persepsi kepuasan nasabah terhadap pelayanan penyaluran KUR pada Bank Rakyat Indonesia (BRI) Unit Tomohon Utara Kota Tomohon mengambil 24 indikator sebagai tolak ukur dalam penelitian ini, dimana masing masing terbagi dalam 7 (Tujuh) bagian yaitu bukti produk (product), harga/suku bunga biaya mendapatkan KUR (price), Tempat (place), promosi (promotion), orang (people),bukti fisik (physical evidendce) dan proses (process).

Untuk mengetahui letak kepuasan nasabah dalam persepsi nasabah terhadap penerapan 7P dalam pemasaran produk KUR Bank Rakyat Indonesia (BRI) Unit Tomohon Utara Kota Tomohon, maka perlu dihitung jumlah keseluruhan skor pada setiap kriterium, dimana sesuai hasil penelitian ini skor mencapai 8914. Pada penelitian ini, jumlah skor ideal (skor tertinggi), yaitu 10560 (tinggi) dan jumlah skor terendah yaitu 2112 (rendah), berdasarkan data yang diambil dari 24 intsrumen pernyataan yang diajukan kepada 88 responden. Berdasarkan tabel 6 yaitu physical evidence (bukti fisik) dapat dilihat bahwa total skor physical evidence 1377, indeks kepuasan nasabah yaitu 79.94 dengan interpretasi Setuju (S), disebabkan oleh skor dari pernyataan : kesediaan tempat parkir yang memadai hanya $57 \%$ dengan interpretasi Cukup Setuju (CS), yang berarti tempat parkir Bank Rakyat Indonesia (BRI) Unit Tomohon Utara Kota Tomohon memiliki tempat parkir yang kurang memadai dan membuat nasabah kurang nyaman. Namun indikator-indikator yang lain dari 7P seperti : product, price, place, promotion, people and process dengan penilaian dari nasabah, nasabah merasa Sangat Setuju (SS), maka letak indeks persepsi kepuasan nasabah dalam persepsi nasabah terhadap penerapan 7P dalam pemasaran produk KUR Bank Rakyat Indonesia (BRI) Unit Tomohon Utara Kota Tomohon dapat dilihat pada gambar 1 .

Keterangan kriteria interpretasi skor kepuasan Nasabah :

Angka 0\%-20\%= Sangat Tidak Setuju

Angka 20\%-40\%= Tidak Setuju

Angka $40 \%-60 \%=$ Cukup Setuju

Angka $60 \%-80 \%=$ Setuju

Angka $80 \%-100 \%=$ Sangat Setuju

Berdasarkan hasil analisis menggunakan skala likert, maka dapat diketahui bahwa angka indeks persepsi kepuasan nasabah terhadap pelayanan penyaluran KUR Bank Rakyat Indonesia (BRI) unit Tomohon Utara Kota Tomohon berada pada titik $84.41 \%$ dan tergolong Sangat Setuju (SS).

$$
\begin{gathered}
\text { Tingkat kepuasan Nasabah }=\frac{\text { Jumlah Skor Hasil Pengumpulan Data }}{\text { Iumlah skor ideal (tertinggi) }} \times 100 \% \\
\text { Tingkat kepuasan Nasabah }=\frac{8914}{10560} \times 100 \%=84.41 \%
\end{gathered}
$$

Dengan internrestasi nilai :

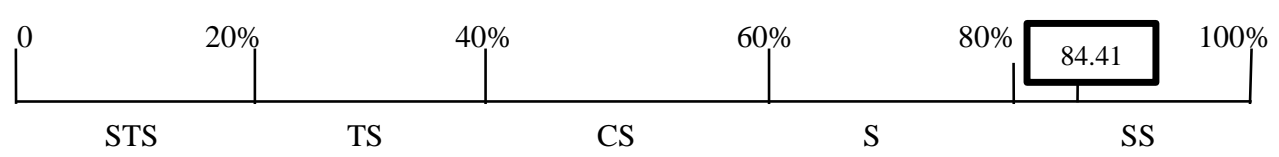

Tabel 28. Rekapitulasi Total Skor, Indeks Kepuasan dan Interpretasi Nilai

\begin{tabular}{ccccc}
\hline No & Kategori & Total Skor & Indeks Kepuasan (\%) & Interpretasi \\
\hline 1 & Product & 1151 & 87.19 & Sangat Setuju \\
2 & Price & 1851 & 84.18 & Sangat Setuju \\
3 & Place & 1081 & 81.89 & Sangat Setuju \\
4 & 780 & 88.63 & Sangat Setuju \\
5 & Promotion & 1145 & 86.74 & Sangat Setuju \\
6 & People & 1377 & 79.94 & Setuju \\
7 & Physical Evidence & 1528 & 86.81 & Sangat Setuju \\
\hline
\end{tabular}

Sumber : Diolah dari data primer 


\section{KESIMPULAN DAN SARAN}

\section{Kesimpulan}

Persepsi Nasabah Terhadap Penerapan 7P Dalam Pemasaran Produk KUR Bank Rakyat Indonesia (BRI) Unit Tomohon Utara Kota Tomohon, berada pada kategori Sangat Setuju (SS) dengan hasil $84.41 \%$. Artinya nasabah merasa sangat setuju dengan product, price, place, promotion, people, physical evidence dan process penyaluran KUR pada Bank Rakyat Indonesia (BRI) Unit Tomohon Utara Kota Tomohon. Berdasarkan physical evidence (bukti fisik) dapat dilihat bahwa total skor physical evidence 1377, indeks kepuasan nasabah yaitu 79.94 dengan interpretasi setuju (S), disebabkan oleh skor dari pernyataan kesediaan tempat parkir yang memadai hanya $57 \%$ dengan interpretasi cukup setuju (CS), yang berarti tempat parkir Bank Rakyat Indonesia (BRI) Unit Tomohon Utara Kota Tomohon kurang memadai dan membuat nasabah merasa kurang nyaman.

\section{Saran}

Untuk meningkatkan kepuasan nasabah melalui ketujuh variabel yang di teliti, maka pihak Bank Bank Rakyat Indonesia (BRI) Unit Tomohon Utara Kota Tomohon harus meningkatkan pelayanan dan memperhatikan physical evidence (bukti fisik) seperti kesediaan tempat parkir agar diperhatikan oleh pihak Bank Rakyat Indonesia (BRI) Unit Tomohon Utara Kota Tomohon

\section{DAFTAR PUSTAKA}

Anonimous, 1992. Undang- undang no. 7 ayat 1. Tentang Perbankan. www.lps.go.id (pdf) (diakses, 3 Desember 2016).

Anonimous, 1998. Undang- undang Republik Indonesia no. 10 Tahun 1998. Tentang Perubahan Undang-undang Nomor 7 Tahun 1992 tentang Perbankan. www.hukumonline.com (pdf) (diakses 17 September 2016).

Anonimous, 2014.Mengelola Bank Komersial.Ikatan Bankir Indonesia.Modul Sertifikasi Tingkat \& General Banking. Ulyabookstore.com> mengelola-bankkomersial (pdf) (diakses 20 Agustus 2016)

Anonimous, 2015.Bahan Ajar Perkuliahan.Bank dan Pasar Modal.Fakultas Ekonomi dan Bisnis. Universitas Sam Ratulangi. Sutaryofe.staff.uns.ac.id (pdf) (diakses 17 September 2016).
Firmansyah, D., 2013. Efektifitas Kebijakan Pemberian Kredit Usaha Rakyat (KUR) Mikro Berdasarkan Surat Edaran Direksi Nose : S.09cDIRADK/032010 Atas Keuntungan Kredit Usaha Rakyat (KUR) Mikro (Studi Di Bank Rakyat Indonesia Unit Cabang Madiun). Jurnal Kementrian Pendidikan Dan Kebudayaan Fakultas Hukum Universitas Brawijaya.

Fitriani. 2012. Pengaruh Ratio Keuangan Bank Terhadap Penyaluran Kredit Modal Kerja.Skripsi Fakultas Ekonomi Universitas Andalas.

Hasibuan. 1996. Dasar-Dasar Perbankan.Penerbit PT Bumi Aksara.

Irianto, S.G., 2012. Pedoman Teknis Kredit Usaha Rakyat (KUR) Sektor Pertanian. Jakarta: Direktorat Pembiayaan Pertanian. Direktorat Jendral Prasarana Dan Saran Penelitian Pertanian. Kementrian Pertanian.

Kerin, A.R., dan Peterson, A.R. 2015. Pemasaran Strategi. Edisi Keseblas. Jilid I. Penerbit Indeks, Jakarta.

Kotler, P. dan Armstrong, G., 2001. PrinsipPrinsip Pemasaran.

Lipiyoadi. 2001. Manajemen Pemasaran Jasa: Teori dan Praktik. Penerbit: Salemba Empat.

Lupiyoadi, dan Kotler, 2008, dalam Lauwy, Payangan, Murnir.Pengaruh Strategi Bauran Pemasaran Terhadap Keputusan Nasabah Dalam Memilih Kartu Kredit Pada PT BANK Tbk.Cabang Utama Makasar.Tesis Program Magister Manajemen Fakultas Ekonomi Universitas Hasanuddin.Diakses 17 Sepetember 2016.

Manurung. 2004. Uang Perbankan Dan Ekonomi Moneter. Jakarta Pratama Rahardja.

Sunyoto. Danang. 2014.Praktik Riset Perilaku Konsumen.CAPS (center of academic publishing services. Jl. Cempaka putih No.8. Yogyakarta)

Thesman, E dan I.G.B.R. Utama. 2010. Analisis Kinerja Menggunakan 7P (Marketing Mix). Fakultas Ekonomi Universitas Dhyana Pura, Bali. Kepuasan Pelanggan Terhadap Pelayanan PDAM Kota Denpasar. ISSN 1410-4628. Volume 12 No. 1. Jurnal. Fakultas Ekonomi Universitas Udayana, Denpasar Bali. 